\title{
DESAFIOS DA GESTÃo COSTEIRA INTEGRADA DA REGIÃO DOS LAGOS (RJ): UMA ANÁLISE BASEADA NA VULNERABILIDADE COSTEIRA E NOS SERVIÇOS ECOSSISTÊMICOS DA GEODIVERSIDADE
}

\author{
Flavia Lins-de-Barros'; Kátia Leite Mansur² \\ 1. Departamento de Geografia da Univ. Federal do Rio de Janeiro \\ 2. Departamento de Geologia da Univ. Federal do Rio de Janeiro
}

\section{Resumo}

O presente trabalho propõe apontar os principais desafios para a gestão costeira da Região dos Lagos (RJ) tendo como conceitos norteadores a vulnerabilidade costeira integrada e os serviços ecossistêmicos da geodiversidade. Através dessa abordagem, foi possível identificar e destacar os principais problemas da zona costeira da região, em especial a erosão costeira e os efeitos das ressacas, a pressão urbana e turística nos ecossistemas costeiros, a fragilidade econômica dos municípios, e as ameaças à geodiversidade. Esperase, com a análise espacial desses problemas, contribuir para a melhor gestão costeira integrada e para a conservação ambiental da região.

Palavras-chave: Gestão costeira integrada; vulnerabilidade costeira; serviços ecossistêmicos; geodiversidade.

\begin{abstract}
The present paper aims identify the challenges for coastal zone management at Região dos Lagos (Rio de Janeiro, Brazil) having as major concepts the integrated coastal vulnerability and geodiversity services. Thought this approach, it was possible to identify and highlight the major problems of the coastal zone of this region, with special attention for coastal erosion and storms effects, urban and touristic pression on coastal ecosystems, economic fragility, and threats to geodiversity. Is expect, with the spatial analyses of these issues, to contribute to better integrated coastal management and environmental conservation.
\end{abstract}

Key words: integrated coastal management, coastal vulnerability, ecosystems services, geodiversity.

A s zonas costeiras são áreas de concentração de múltiplos usos e interesses. Merecem destaque as atividades portuárias, o turismo, a pesca e também a extração de importantes recursos minerais. Ao longo da história estas características resultaram na enorme concentração demográfica das áreas costeiras e no seu elevado valor imobiliário e turístico. Tais características, somadas aos dinâmicos processos geobiofísicos e à variedade de paisagens que ocorre na interface terra-mar, tornam as cidades costeiras foco de graves problemas socioambientais, relacionados principalmente à degradação dos ecossistemas costeiros e marinhos, à erosão costeira e instalação de áreas de riscos, à intrusão salina em aquíferos, e aos conflitos de uso.

A Região dos Lagos, localizada no estado do Rio de Janeiro, é um bom exemplo deste cenário, uma vez que contém praias com elevada vulnerabilidade física à erosão costeira, lagunas 
fortemente impactadas pela falta de saneamento básico adequado, ocupação irregular de dunas e costões rochosos, descaracterização das paisagens por ocupação urbana ou turística, além de efeitos socioambientais associados à exploração de óleo e gás. O objetivo do presente trabalho é apresentar os desafios para a gestão costeira integrada da Região dos Lagos, visando contribuir com a definição de ações prioritárias a partir da identificação de questões relacionadas à dinâmica geomorfológica das praias, à pressão urbana e turística sobre os ecossistemas costeiros e à ameaça ao patrimônio geológico existente da região.

\section{Área de estudo}

A Região dos Lagos foi instituída oficialmente em 1997 pelo artigo $1^{\circ}$ da Lei Estadual (RJ) $n^{\circ}$ 2829/97, como segue:

"Art. $1^{0}$ - Fica denominada Região dos Lagos Fluminenses, o conjunto dos Municípios de Maricá, Saquarema, Araruama, São Pedro da Aldeia, Cabo Frio e Arraial do Cabo, Iguaba Grande, Armação de Búzios, Casimiro de Abreu e Rio das Ostras".

Em 2001, a Lei Complementar $n^{\circ} 97$ alterou o conjunto de municípios que integra a Região dos Lagos (denominada de Microrregião dos Lagos), acrescentando o município de Silva Jardim e retirando Maricá que passou a integrar a Região Metropolitana. No presente trabalho foi adotada a composição original do ano de 1997, pelo entendimento de que Maricá possui características ambientais comuns aos outros municípios. Assim, a área de estudo é constituída por dez municípios, dos quais apenas Iguaba Grande e São Pedro da Aldeia não se encontram defrontes para o mar, embora apresentem importante orla lacustre pela presença da Lagoa de Araruama (Figura 1).

Em termos geomorfológicos, a Região dos Lagos pode ser enquadrada em duas diferentes regiões costeiras do estado, conforme descrito por Muehe e Valentini (1998) e, mais recentemente, por Muehe e Lins-de-Barros (2016). Assim, distingue-se a paisagem costeira da porção sul, compreendida entre os municípios de Maricá e Arraial do Cabo, daquela compreendida entre Cabo Frio e Rio das Ostras. A porção sul é marcada pela presença de extensos arcos praiais, associados a cordões litorâneos que ocorrem em forma de duplos cordões cuja evolução está associada às mudanças do nível do mar no Quaternário. O cordão mais interiorizado, data do Pleistoceno (120.000 anos A.P.) e sua origem está associada à penúltima transgressão marinha (TURCQ et al. 1999). O cordão frontal, por sua vez, tem sua evolução associada à última transgressão marinha ocorrida no Holoceno por volta de 5.000 anos A.P. A característica geomorfológica mais significativa dessa porção sul é o conjunto de lagunas desenvolvido à retaguarda dos cordões litorâneos, cuja presença motivou a designação da região. As lagunas maiores, com destaque para a de Araruama, localizam-se à retaguarda do cordão litorâneo mais interiorizado, enquanto as menores encontram-se comprimidas entre o reverso do cordão litorâneo frontal e a frente do cordão mais interiorizado, completamente isoladas de qualquer aporte fluvial. Merece destaque a presença de estruturas estromatolíticas se desenvolvendo nas águas hipersalinas no sistema lagunar de Araruama (VASCONCELOS, 1994), o que transforma estas lagunas em verdadeiros laboratórios para a compreensão da origem da vida na Terra e, por isto, são considerados patrimônio geológico de importância mundial (MANSUR, 2010). 


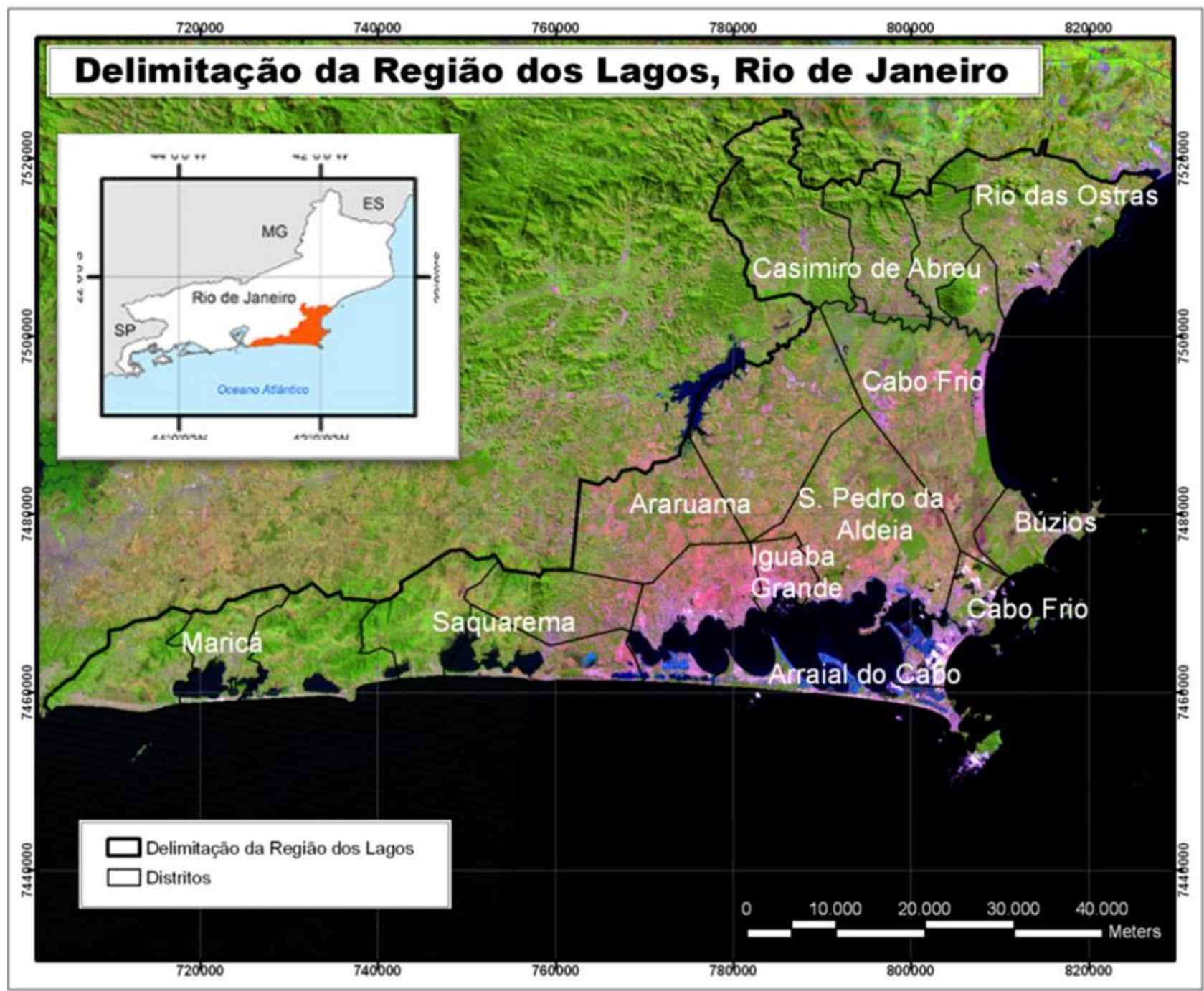

Figura 1. Localização da Região dos Lagos (RJ) e mapa da divisão dos municípios e distritos que compõem a a compõem. Fonte: Lins-de-Barros (2010).

Existem ainda áreas de antigas lagunas que foram colmatadas e substituídas por brejos e alagadiços. Também é comum em toda a faixa litorânea deste segmento a presença de vegetação de restinga e dunas frontais. As praias são extensas, com raras interrupções por afloramentos rochosos. Porém, pode ser observada a presença de beachrocks emersos em Jaconé (MANSUR et al. 2011; MANSUR et al. 2013) e na llha do Cabo Frio (CASTRO et al. 2012) - os únicos do estado nessa condição de afloramento - e submersos em Itaipuaçu (IGNARRA, 1989). Vale ressaltar o papel de proteção que tais rochas desempenham face à erosão das praias. A litologia predominante nesse trecho corresponde ao Complexo Região dos Lagos, representante do embasamento paleoproterozoico, composto por ortognaisses e ortoanfibolitos, em importante contato tectônico com as rochas paraderivadas da Sucessão Palmital na localidade de Ponta Negra, em Maricá. Na Ilha de Cabo Frio destaca-se a presença de rochas magmáticas plutônicas e subvulcânicas do Paleógeno e na parte continental de Arraial do Cabo os mesmos gnaisses do embasamento, cortados por enxames de diques de diabásio (130 milhões de anos) e alcalinos relativos à intrusão das rochas da llha. 


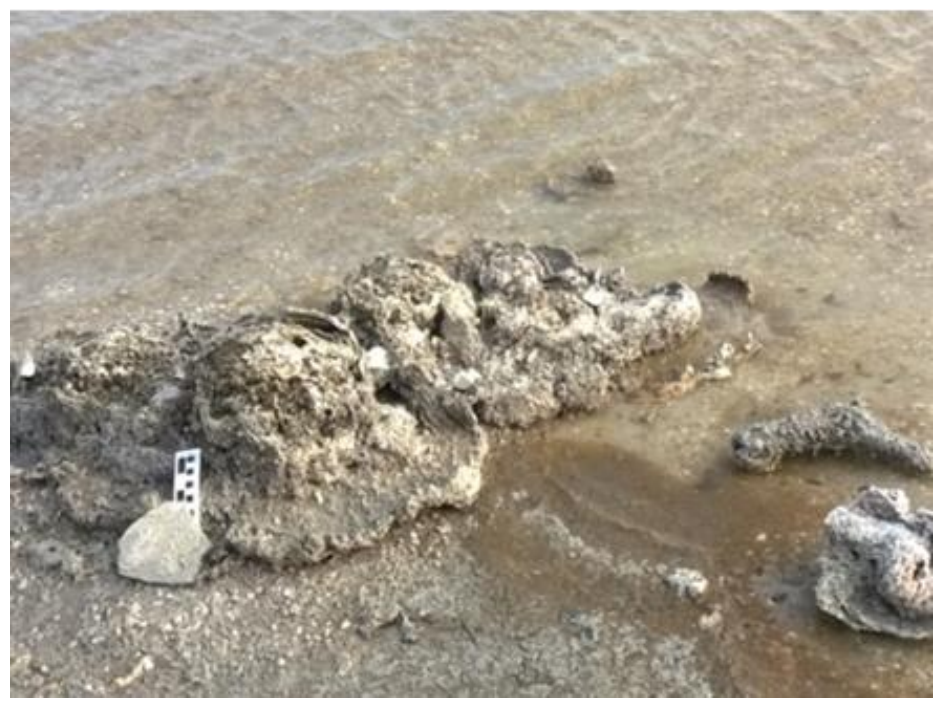

Figura 2. Estromatólitos na Lagoa Vermelha. Foto: Kátia Mansur.

Na parte nordeste da Região, que abrange o gráben de Barra de São João (MOHRIAK; BARROS, 1990) desde o limite dos municípios de Armação dos Búzios e Cabo Frio, chegando até Casimiro de Abreu e Rio das Ostras, a paisagem se transforma em uma planície fluviomarinha com destaque para a foz do Rio São João na divisa dos municípios de Rio das Ostras e Casimiro de Abreu, também merecendo relevância o Morro de São João, intrusão alcalina com 60 milhões de anos que se eleva na planície. O cabo de Búzios apresenta uma geologia particular, com a presença de embasamento cristalino paleoproterozoico, o mesmo descrito para o outro trecho, com intercalações de rochas paraderivadas cambrianas, por meio das quais foi datada a Orogenia Búzios (SCHMITT, 2001). Esse litoral se caracteriza pela alternância entre afloramentos rochosos, especialmente na sua porção peninsular, e planícies costeiras, formadas pela deposição de sedimentos no Quaternário.

A urbanização dos municípios da Região dos Lagos teve acelerado crescimento a partir da década de 1950, principalmente em função da valorização turística e da maior facilidade de acesso à região ${ }^{1}$. Com o asfaltamento da estrada, o afluxo de turistas e moradores sazonais se intensificou gradativamente, passando a dar um salto após a construção da ponte Rio-Niterói, em 1974. A partir daí,outras localidades que antes não faziam parte do circuito turístico, passaram a despertar interesse, como Saquarema, Barra de Maricá e, em menor escala, Itaipuaçu. O crescimento urbano acelerado dos municípios dessa região continuou a ser observado na década de 1990, quando mais uma vez a melhoria de acesso, em função da construção da Rodovia Via-Lagos, foi fator determinante. Atualmente, a população urbana da Região dos Lagos é de aproximadamente 880.000 habitantes.

\footnotetext{
${ }^{1} \mathrm{O}$ impulso decisivo para a atividade turística na região foi a construção da Rodovia Amaral Peixoto no fim da década de 1940 (CASTRO, 1995).
} 


\section{Metodologia}

O presente trabalho pretende contribuir para apontar os principais desafios da gestão costeira da Região dos Lagos (RJ) a partir de dois conceito-chaves: vulnerabilidade costeira integrada e geodiversidade / patrimônio geológico. Para tanto, foi realizada a compilação de estudos científicos e de notícias de jornais sobre a Região dos Lagos; o aprofundamento e atualização da avaliação da vulnerabilidade costeira proposta por Lins-de-Barros (2010); e a adoção do conceito de geodiversidade e patrimônio geológico como elemento importante para se pensar a conservação das paisagens e ecossistemas costeiros. Visando atender ao objetivo de definir prioridades para a gestão costeira na escala regional é realizado um mapeamento síntese da distribuição espacial dos elementos da vulnerabilidade costeira integrada e das categorias de serviços da geodiversidade prestados na região.

O conceito de vulnerabilidade vem sendo debatido na literatura acadêmica há algumas décadas. Conforme destaca Adger et al. (2004), cientistas sociais e cientistas naturais geralmente querem expressar diferentes significados quando usam o termo vulnerabilidade. Com isso, os autores ressaltam que é cada vez mais comum usar os adjetivos socioeconômico, físico, ou biofísico, associados ao termo. Apesar das inúmeras abordagens, parece ser consenso a ideia de que o termo vulnerabilidade está relacionado à resiliência, ou à capacidade de indivíduos, grupos sociais, ecossistemas, ou mesmo os sistemas físicos, de se adaptarem a algum tipo de impacto. Neste sentido, Woodroffe (2007) define vulnerabilidade costeira como sendo o grau com que uma costa pode ser afetada por um impacto, ou sua incapacidade em lidar com as consequências deste. $\mathrm{O}$ autor acrescenta que o impacto pode ser relacionado a eventos naturais, como erosão e inundação litorânea, ou a ações e eventos humanos. Esta definição é muito próxima daquela definida anteriormente pelo IPCC (2001), que afirma que a vulnerabilidade costeira a mudanças climáticas ocorre em função da caraterística, magnitude e taxa de variação climática ao qual um sistema está exposto, sua sensibilidade e sua capacidade adaptativa. Entende-se, portanto, que a vulnerabilidade costeira é uma relação entre o grau de exposição de determinado sistema costeiro a algum tipo de impacto ou distúrbio, e sua capacidade de adaptação ou resiliência (LINS-DEBARROS, 2010). No presente trabalho, este conceito será utilizado para tratar das problemáticas atuais da zona costeira que já vêm impactando as áreas litorâneas, independente das previsões de mudanças climáticas globais. Parte-se da ideia de que as zonas costeiras são intrinsecamente expostas a ressacas do mar e tempestades, além de apresentarem condições ecológicas muito específicas, o que torna seus habitats especialmente expostos a situações extremas, como forte insolação, salinidade excessiva, e déficit hídrico. Em relação aos aspectos sociais, a elevada densidade demográfica e a concentração de diversas atividades econômicas frequentemente resultam na ocupação de áreas ecologicamente frágeis, ou de áreas expostas à erosão e inundação litorânea, levando a situações de risco e degradação ambiental.

Para McFadden (2007), corroborado por Lins-de-Barros (2017), para se usar o conceito de vulnerabilidade costeira em seu maior potencial nas tomadas de decisão, as abordagens física, ecológica e socioeconômica precisam estar integradas. Desta forma, adota-se aqui o termo Vulnerabilidade Costeira Integrada, introduzido por Lins-de-Barros (2007). 
O conceito de serviços ecossistêmicos da geodiversidade, por sua vez, foi introduzido no século XXI (ENGLISH NATURE, 2002; GRAY, 2004; GRAY 2013), com base na economia dos ecossistemas, estabelecida a partir da Avaliação Ecossistêmica do Milênio (MEA, na sigla em inglês), criada no âmbito da Organização das Nações Unidas para avaliar as consequências das mudanças nos ecossistemas e identificar as bases científicas necessárias para melhorar a conservação e o uso sustentável desses sistemas, garantindo sua contribuição para a humanidade, na forma de água limpa, alimentos, produtos florestais, controle de inundação, e recursos naturais $^{2}$. No que se refere à geodiversidade, Gray (2013), sugere a adoção de 25 serviços abióticos prestados pelos ecossistemas (Figura 3). Uma análise do valor da geodiversidade sob esse prisma foi desenvolvido por Silva (2016) e Silva e Nascimento (2016) para a região de Natal (RN).

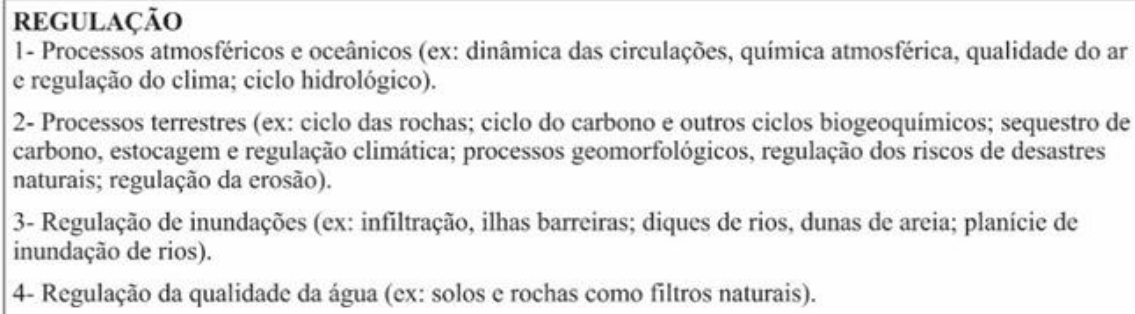

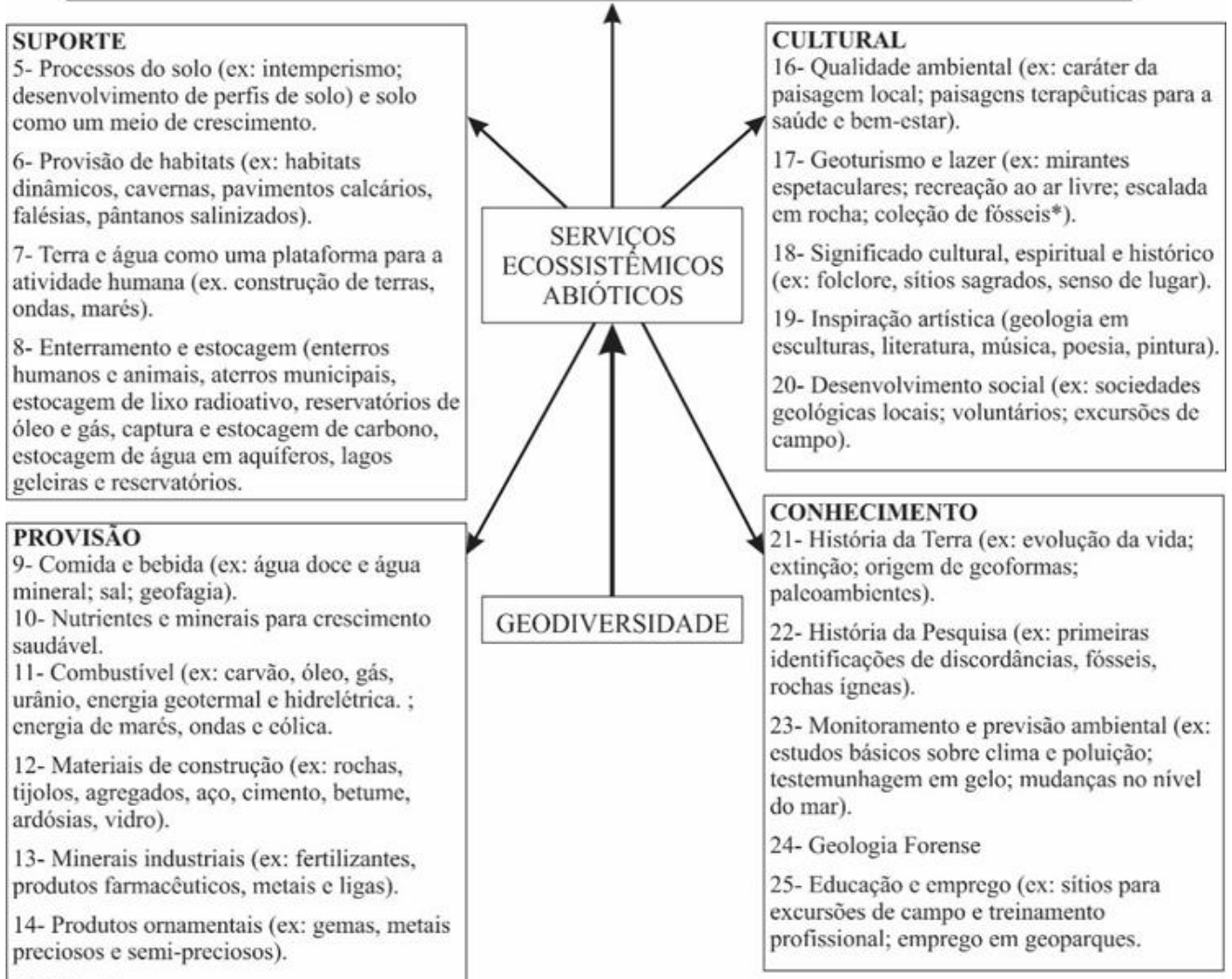

Figura 3. O papel da Geodiversidade na geração de bens e serviços (traduzido de Gray, 2013).

\footnotetext{
${ }^{2}$ http://www.millenniumassessment.org/en/Index-2.html
} 
A partir destes dois conceitos descritos, o presente trabalho foi desenvolvido a partir das seguintes etapas:

- Atualização da classificação da vulnerabilidade física à erosão costeira e efeitos de eventos de ressaca;

- Avaliação da pressão demográfica e turística sobre os principais ecossistemas costeiros;

- Levantamento dos serviços ecossistêmicos da geodiversidade da zona costeira da região, onde foram selecionados alguns pontos de relevância, classificados como Patrimônio Geológico pelo seu alto valor científico, conforme definição de Brilha (2016), e que se encontram ameaçados pelo licenciamento de empreendimentos diversos ou ocupação urbana descontrolada;

- Indicação dos principais desafios para a gestão costeira da Região dos Lagos.

Em relação ao aprofundamento e a atualização da proposta metodológica de Lins-deBarros (2010), foi dada ênfase à análise da erosão costeira das praias e à atualização dos dados referentes à pressão urbana sobre ecossistemas lagunares. Dados de monitoramento de praias apresentados posteriormente por Muehe (2011), Fernandez et al. (2011) e Bulhões et al. (2016), além de pesquisas sobre notícias de ressacas no acervo do Jornal O Globo e em jornais locais que permitiram confirmar alguns resultados, assim como atualização de algumas classes de vulnerabilidade previamente definidas.

Em relação à pressão urbana e turística sobre os ecossistemas costeiros, foram utilizados dados do censo demográfico de 2010 do IBGE (2010), que serviram de base para mapeara distribuição populacional e as condições sanitárias por setores censitários no entorno das lagunas, além da estimativa de habitantes no entorno de dunas.

Além disso, foram realizadas observações in loco onde a previsão de empreendimentos de grande porte tem provocado manifestações de moradores, ambientalistas e cientistas devido ao potencial de causar danos aos ecossistemas da região.

A análise metodológica para enquadramento dos sítios selecionados segundo as definições dos serviços ecossistêmicos prestados pela geodiversidade foi realizada utilizando-se os critérios de Regulação, Suporte, Provisão, Cultural e de Conhecimento propostos por Gray (2013).

\section{Resultados}

A compilação de estudos científicos e de notícias de jornais sobre a Região dos Lagos permitiu identificar os principais problemas, a seguir descritos, a partir dos quais o presente trabalho se desenvolveu:

1. Erosão e inundação costeiras associadas à ação de ressacas e simulação de cenários de subida do nível do mar;

2. Pressão urbana e turística sobre os ecossistemas costeiros e a geoversidade; 
3. Fragilidade econômica dos municípios em função da dependência da atividade turística e/ou da indústria de óleo e gás.

A linha de costa da Região dos Lagos é composta por $180 \mathrm{~km}$ de praias arenosas e $62 \mathrm{~km}$ de costões rochosos. Dentre as praias arenosas, $81 \mathrm{~km}$ (aproximadamente 44\%) possuem elevada vulnerabilidade à erosão costeira associada à exposição de ondas e às características geomorfológicas do litoral (LINS-DE-BARROS, 2010). Esse percentual é muito elevado e, por si só, alerta para a necessidade de se estabelecer critérios adequados para o uso da orla desta região. Dentre as praias consideradas com elevada vulnerabilidade, $53 \mathrm{~km}$ (aproximadamente $30 \%$ do total das praias da região) já apresentaram impactos em infraestruturas urbanas durante eventos de ressaca. Em Maricá e Saquarema os prejuízos e impactos de uma única ressaca ocorrida no ano de 2001 foi da ordem de R $\$ 3$ milhões (LINS-DE-BARROS et al., 2005) e resultaram em uma série de medidas adaptativas levadas a cabo pelos proprietários das casas à beira-mar (LINS-DEBARROS et al, 2016). A recuperação da praia após a tempestade parece ter sido total, não havendo indicação de uma tendência de recuo da linha de costa ao comparar perfis topográficos transversais em quase quatro décadas de estudo (MUEHE, 2011). Pinto et al. (2017), no entanto, realizaram monitoramento do arco praial Jaconé - Saquarema entre 2012 e 2016, concluindo, a partir da aquisição de 105 perfis topográficos e coleta de 122 amostras de sedimentos de praia para análise granulométrica, que a praia tem dinâmica moderada a alta, com intensa energia das ondas de tempestades no extremo oeste de Jaconé, diminuindo em direção a Saquarema.

Esta capacidade de recuperação também é observada em outras praias da região, como na praia da Massambaba, onde o monitoramento mensal ao longo de 12 anos revelou que, tanto a largura da praia quanto o volume de areia ao longo de um perfil transversal, não apresentaram tendência de diminuição, apesar das amplas variações típicas de uma praia de estágio morfodinâmico intermediário (MUEHE, 2011).

No ano de 2010, forte ressaca provocou erosão e formação de escarpas acentuadas em diversas praias da região, como apontam Fernandez et al. (2011). No entanto, novamente, monitoramentos da variação de volume entre 2007 e 2013, realizados por Bulhões et al. (2016), apontam oscilações que demonstraram recuperação após ressacas. Essa elevada capacidade das praias em se reestabelecer, também denominada de resiliência, não elimina o risco às construções localizadas muito próximas às mesmas (MUEHE, 2011), uma vez que durante fortes ressacas a praia apresenta grande variação na extensão e volume. A ocupação dentro desta faixa dinâmica é, portanto, muito arriscada, além de poder alterar o ajuste natural deste sistema, uma vez que em muitos casos a duna frontal é eliminada.

Em Maricá, Lins-de-Barros (2005) observou que segmentos com mesmo grau de exposição às ressacas, tiveram impactos diferentes em função do afastamento das construções em relação à berma da praia, e da presença de dunas frontais e vegetação de restinga. Em trabalho posterior, Lins-de-Barros e Muehe (2013) alertam que apenas $20 \%$ das praias da região possuem dunas frontais e, destas, apenas 18\% eram recobertas por vegetação de restinga.

$\mathrm{Na}$ praia do Forte, em Cabo Frio, tal problemática representa um alerta, pois apesar das características geomorfológicas e oceanográficas dessa praia (tais como presença de campo de dunas e menor grau de exposição às ondas do que as praias mais ao sul) apontarem moderada vulnerabilidade, a ressaca ocorrida no ano de 2010 resultou em impactos na avenida litorânea. 
Neste caso, nota-se o avanço da urbanização para próximo da faixa de areia, o que pode ter sido um fator determinante para tal episódio.
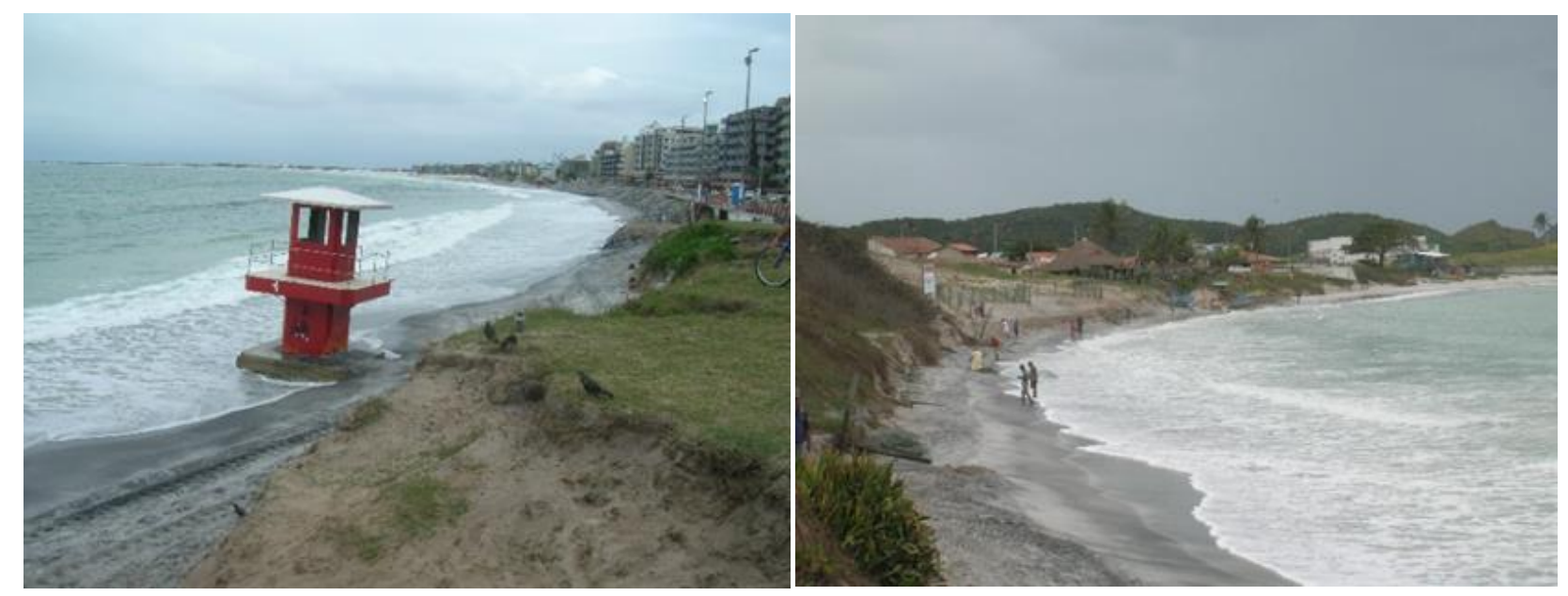

Figura 4. Praia do Forte após ressaca ocorrida no ano de 2010. Fotos: Kátia Mansur.

O problema é ainda mais grave em praias onde foi detectada baixa capacidade de recuperação natural do estoque sedimentar. Este é o caso das praias Virgem, do Abricó e da Tartaruga em Rio das Ostras, onde comparações de fotografias aéreas e de monitoramentos de praias por mais de 10 anos (LINS-DE-BARROS, 2010; MUEHE, 2011; CASTRO et al., 2011), revelaram tendência de recuo da linha de costa de aproximadamente $1 \mathrm{~m} / \mathrm{ano}$, podendo chegar a 1,4 m/ano no caso da praia da Tartaruga (CASTRO et al., 2011).

Nota-se, ainda, que Arraial do Cabo e Armação dos Búzios possuem praias mais abrigadas, localizadas nos cabos que se projetam para dentro do mar, e formam praias pequenas e rochosas em enseadas com diferentes orientações (MUEHE; LINS-DE-BARROS, 2016). Nestas, não se observa erosão costeira, embora em alguns casos a faixa de areia seja muito estreita em função da ocupação por casas na zona intermarés (Figura 5).

Cabral et al. (2018) identificaram e dataram, no canal da Marina Porto Búzios, depósitos sedimentares associados à passagem de um ciclone extratropical na área há aproximadamente 108 anos. Segundo esses autores, a "passagem desse evento destrutivo rompeu o cordão litorâneo que separa o mar da planície costeira, projetando-se para as regiões mais abrigadas da costa, constituídas principalmente por pântanos atuais" (p. 140).

Considerando a previsão de subida do nível do mar, as áreas atualmente mais vulneráveis certamente teriam sua vulnerabilidade à erosão aumentada, e algumas praias atualmente menos vulneráveis poderiam sofrer recuo e inundações litorâneas mais intensas em função das características do relevo e da ausência de dunas. Este é o caso da praia de Unamar, em Cabo Frio, onde Lins-de-Barros (2010) aponta para um recuo potencial de mais de 400 metros, considerando a 
regra de Bruun (1962), em caso de subida de um metro do nível do mar conforme previsto para os próximos 100 anos.

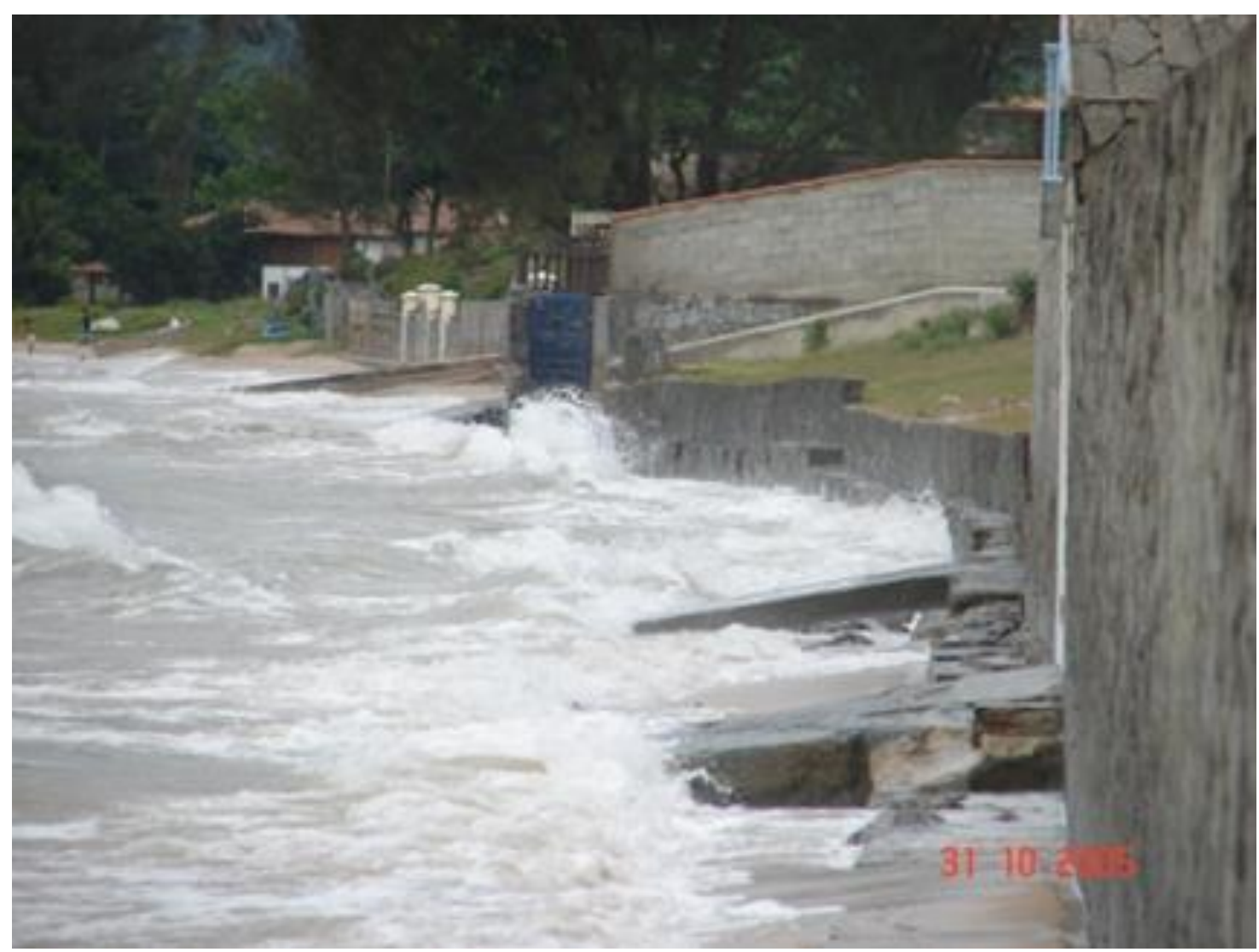

Figura 5. Foto de uma praia no município de Armação dos Búzios onde a faixa de areia desaparece durante a maré alta ou em dias com ondas mais fortes. Foto: Dieter Muehe.

Em relação à pressão urbana e turística sobre os ecossistemas costeiros, destaca-se no presente trabalho a poluição das lagunas, a ocupação na borda das dunas e a ocupação em costão rochoso. Avelar e Tokarczyk (2014) realizaram um estudo utilizando fotografias aéreas de 1976 e imagens de satélite (Landsat 1990 e Geoeye 2012) para a região da Lagoa de Araruama no período de 1976 a 2012, e os resultados mostram a dimensão do problema de ocupação, conforme Tabela 1, onde as áreas construídas aumentaram mais de $200 \%$ e a vegetação densa diminuiu em cerca de $55 \%$, as áreas arenosas em cerca de $36 \%$ e os corpos d'água em quase $10 \%$. 
Tabela 1. Mudança do uso e cobertura do solo entre 1976 e 2012 na Região dos Lagos

\begin{tabular}{l|rrr}
\hline \multirow{2}{*}{ Uso das terras } & \multicolumn{3}{c}{ Magnitude das mudanças (\%) } \\
\cline { 2 - 4 } & $\mathbf{1 9 7 6} \mathbf{a} \mathbf{1 9 9 0}$ & $\mathbf{1 9 9 0} \mathbf{a ~ 2 0 1 2}$ & $\mathbf{1 9 7 6} \mathbf{~ a ~ 2 0 1 2}$ \\
\hline Vegetação densa & $-28,47$ & $-36,92$ & $-54,88$ \\
Vegetação esparsa & 14,95 & $-1,41$ & 13,33 \\
Solo nu & $-3,8$ & 24,31 & 19,59 \\
Área construída & 32,99 & 128,46 & 203,83 \\
Salina & $-65,71$ & $-55,98$ & $-84,91$ \\
Areia & $-69,23$ & 109,27 & $-35,61$ \\
Corpos D'água & 9,19 & $-17,19$ & $-9,58$ \\
\hline
\end{tabular}

Fonte: Modificado e traduzido de Avelar e Tokarczyk (2014)

Isto comprova que a pressão urbana sobre os sistemas lagunares pode ser considerada muito elevada, com a situação agravada pela falta de tratamento de esgoto adequado, conforme revelam os dados do censo de 2010 do IBGE (Figura 6).

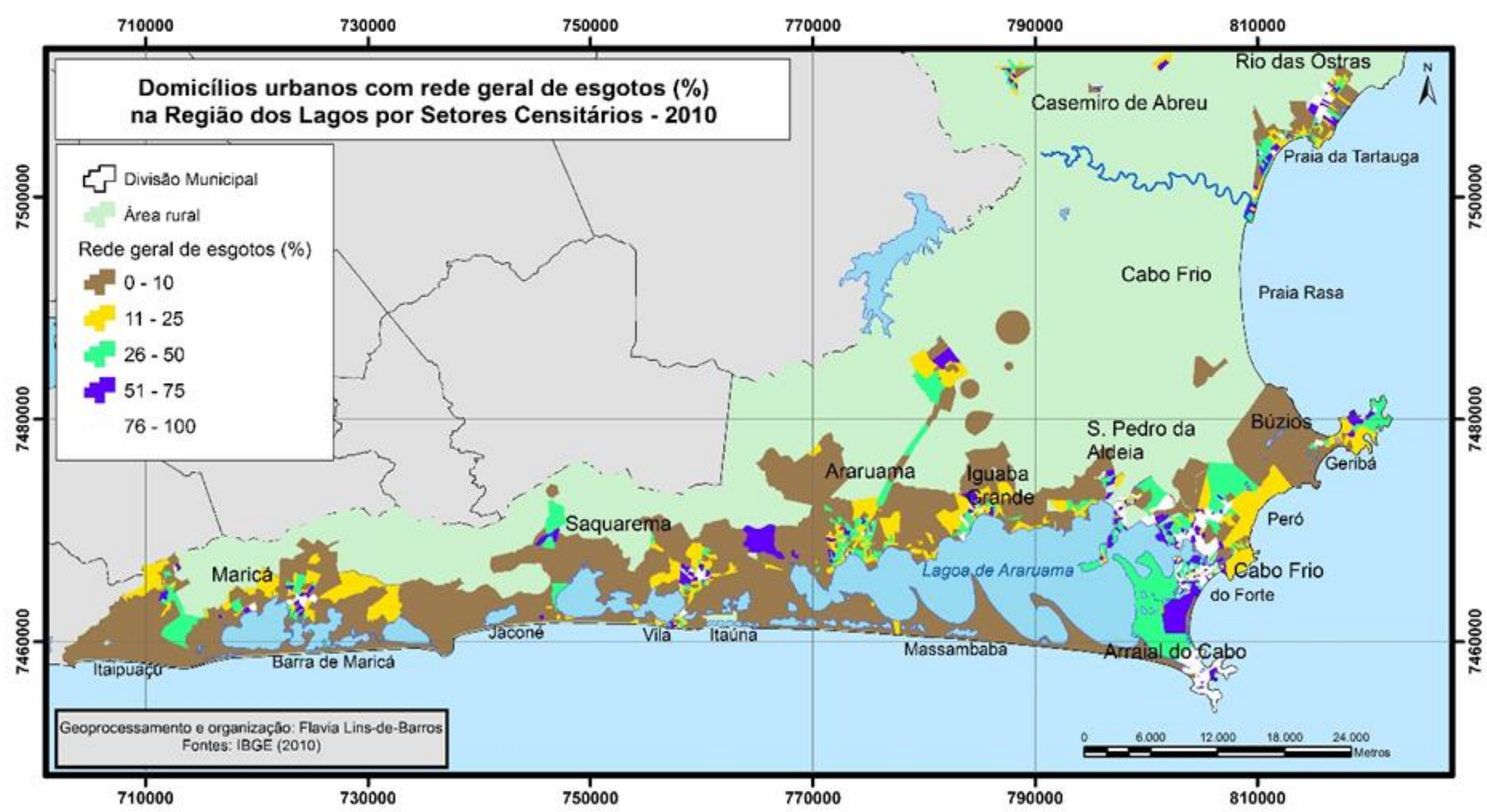

Figura 6. Domicílios urbanos com rede geral de esgotos na Região dos Lagos - 2010. Fonte: Compliação de dados dos Setores Censitário do IBGE (2010).

Considerando o número de pessoas vivendo em domicílios com lançamento de esgoto direto nos rios e nas lagoas, foi calculado o volume de esgoto total lançado por dia sem qualquer tipo de tratamento, considerando a produção média de 140 L/dia per capita (Tabela 2). A Lagoa 
de Maricá é a mais impactada, com aproximadamente 10,5 mil litros por dia de esgoto lançados diretamente nas lagoas ou nos canais fluviais que deságuam nela, considerando apenas a população que vive nos domicílios localizados imediatamente no entono deste sistema de lagunas no ano de 2010. Todas as lagunas da região são consideradas confinadas e com tempo elevado de renovação de suas águas, uma vez que se conectam ao mar por poucos e pequenos canais de marés. No entanto, deve-se destacar que os canais de Itajuru, Ponta Negra e Saquarema, respectivamente localizados nas lagoas de Araruama, Maricá e Saquarema, são mantidos abertos por obras e dragagens periódicas. Eles não são suficientes para uma renovação rápida das águas, porém permitem trocas de águas com salinidades diferentes, uma vez que Araruama é hipersalina e Maricá e Saquarema são salobras.

Ainda na Tabela 2, é possível observar que o número de domicílios com tratamento de esgoto por rede geral é muito baixo em todos os casos, chegando a não mais que $12 \%$ dos domicílios no entorno dos sistemas lacustres de Maricá e Saquarema, e pouco mais que 33\% no entorno da lagoa de Araruama. Nota-se, ainda, que o número de domicílios com fossas rudimentares e fossas sépticas é muito elevado, representando aproximadamente $90 \%$, 77\% e 64\% dos domicílios do entorno das lagoas de Saquarema, Maricá e Araruama, respectivamente. Esta situação representa elevado potencial de poluição do lençol freático, dada a característica arenosa do solo, o que somado ao grande número de poços e a inundações litorâneas que ocorrem nestas áreas aumenta o risco de contaminação, conforme já alertado por Lins-de-Barros e Muehe (2010).

Em Saquarema previsões e modelagens da poluição realizadas por Azevedo (2005) constatam que mesmo com a abertura do canal Barra Franca permanentemente o problema de eutrofização não será melhorado caso a carga de nutrientes no sistema não diminua.

Tabela 2. Lagunas segundo condições de tratamento de esgoto sanitário

\begin{tabular}{|c|c|c|c|}
\hline & L. de Araruama & L. de Saquarema & L. de Maricá \\
\hline $\mathrm{N}^{\circ}$ de residentes no entorno (Total) & 30.568 & 6.901 & 14.099 \\
\hline $\begin{array}{l}\text { Domicílios do entorno com lança- } \\
\text { mento de esgoto in natura }\left(n^{0}\right)\end{array}$ & 163 & 45 & 265 \\
\hline $\begin{array}{c}\text { Domicílios do entorno com trata- } \\
\text { mento por rede geral }\left(n^{\circ}\right)\end{array}$ & 3.450 & 185 & 529 \\
\hline $\begin{array}{l}\text { Domicílios do entorno com fossas } \\
\text { rudimentares }\left(n^{\circ}\right)\end{array}$ & 1.563 & 1.062 & 2.159 \\
\hline $\begin{array}{l}\text { Domicílios do entorno com fossas } \\
\text { sépticas }\left(n^{0}\right)\end{array}$ & 4.992 & 990 & 1669 \\
\hline $\begin{array}{c}\text { Vazão de esgoto lançado in natura } \\
\text { (L/Dia) }\end{array}$ & 6.873 & 6.721 & 10.590 \\
\hline
\end{tabular}

Fonte: Informações compiladas a partir do cruzamento dos dados por setores censitários do IBGE (2010) com o mapeamento das lagunas no programa ArcMAP 10.1

Este cenário é ainda mais preocupante quando se acrescenta a pressão exercida pela chegada de veranistas e turistas em época de alta temporada, uma vez que a Região dos Lagos é a região turística mais importante do estado do Rio de Janeiro. A partir do número de domicílios de uso ocasional (IBGE, 2010) e do número de leitos em hotéis e pousadas (Censo TurisRio 2007) estimou-se que a região recebe por ano aproximadamente 700.000 turistas, ou seja, a po- 
pulação da região praticamente dobra, uma vez que a população urbana total no ano de 2010 era de aproximadamente 880.000 habitantes. No entorno das lagunas, o município de Iguaba Grande se destaca por ter um aumento populacional de quase 200\% (Figura 7).

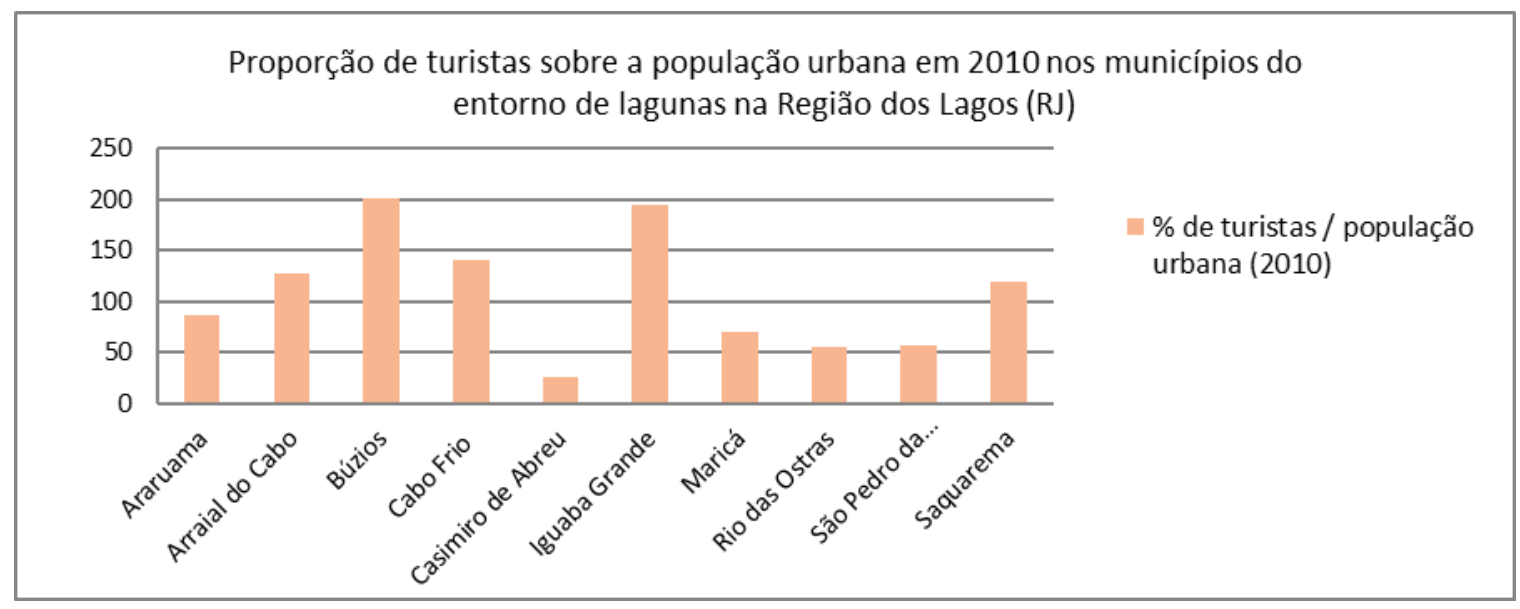

Figura 7. Proporção do número de turistas sobre o total da população urbana nos municípios da Região dos Lagos em 2010. Fonte: Compilação dos dados por setores censitários do IBGE (2010) e do Censo TurisRio (2007).

A intensa atividade turística somada à atração de residentes em função da indústria de óleo e gás da bacia de Campos e Santos, além de representar aumento na pressão sobre os ecossistemas, traz outra preocupação para esses municípios: a fragilidade da dependência econômica associada à essas atividades. Municípios como Araruama e Iguaba Grande vivem quase exclusivamente do turismo de veraneio, e a poluição da lagoa de Araruama já influencia na perda de qualidade ambiental e na diminuição da atração turística. Em Armação dos Búzios existem mais de 200 hotéis e pousadas, e mais de $30 \%$ dos empregos eram vinculados às atividades turísticas no ano de 2005 (LINS-DE-BARROS, 2010). No entanto, na época de veraneio, a cidade sofre ocasionalmente com falta de abastecimento de água para consumo humano, grandes congestionamentos de carros, e outros problemas ambientais nas praias, tais como lixo, superlotação, remoção da vegetação e outros (BARBOSA, 2005), mostrando evidências de uma potencial saturação. Rio das Ostras, também é um bom exemplo deste processo. A cidade teve a maior taxa de crescimento urbano do estado do Rio de Janeiro entre 2000 e 2010, em função do aumento de empregos relacionados à indústria petrolífera. Hoje, tal indústria encontra-se em crise devido aos problemas advindos da diminuição de investimentos da Petrobras e outras empresas, e a cidade já apresenta sinais de decadência. Apesar disso, as cidades de Maricá e Rio das Ostras se destacam ainda em relação ao valor arrecadado de royalties em todo o Brasil como se observa na Tabela 3. Tal constatação aponta a necessidade de se repensar a aplicação deste recurso de maneira adequada às problemáticas costeiras, dialogando assim com a gestão ambiental. 
Tabela 3. Arrecadação de royalties nas cidades da Região dos Lagos e sua colocação nacional.

\begin{tabular}{l|rrr}
\hline \multicolumn{1}{c|}{ Município } & \multicolumn{1}{c|}{ Valor (R\$) } & Colocação Nacional \\
\hline Maricá - RJ & $37.284 .565,11$ & $2^{\circ}$ lugar \\
Rio das Ostras - RJ & $11.997 .322,87$ & $8^{\circ}$ lugar \\
Cabo Frio - RJ & $11.444 .266,52$ & $9^{\circ}$ lugar \\
Armação dos Búzios - RJ & $5.441 .361,78$ & $21^{\circ}$ lugar \\
Casimiro de Abreu - RJ & $5.385 .978,58$ & $23^{\circ}$ lugar \\
Saquarema - RJ & $5.051 .968,88$ & $24^{\circ}$ lugar \\
Arraial do Cabo - RJ & $3.585 .524,28$ & $30^{\circ}$ lugar \\
Araruama - RJ & $1.057 .710,43$ & $99^{\circ}$ lugar \\
São Pedro da Aldeia - RJ & $1.001 .525,14$ & $104^{\circ}$ lugar \\
Iguaba Grande - RJ & $723.323,71$ & $168^{\circ}$ lugar \\
\hline
\end{tabular}

Fonte: ANP (acessados em 6/5/2018).

A região se caracteriza ainda pela presença de campos de dunas muito particulares. Sua ocorrência é facilitada pelos constantes ventos de nordeste, que levam as areias finas das praias em direção aos continentes, e da baixa pluviosidade, que faz com que os sedimentos permaneçam secos e sejam facilmente transportados. Esta última característica se dá em função das baixas temperaturas do mar decorrentes do fenômeno da ressurgência, que ocorre no litoral dessa região. Tal combinação de fatores levou ao desenvolvimento do campo de dunas das praias do Peró, do Forte e do Foguete em Cabo Frio, da praia de Tucuns em Armação dos Búzios, e da praia da Massambaba e de dunas isoladas no Pontal do Atalaia e Ilha do Cabo Frio em Arraial do Cabo (BIDEGAIN, 2002; DIAS et al., 2009; MANSUR; CARVALHO, 2011, entre outros). Em Maricá, encontra-se também importante remanescente de dunas no pós-praia, que preserva ainda uma das mais ricas restingas de todo o estado (por exemplo, SILVA; OLIVEIRA, 1989, ABRANTES; MENDONÇA, 2005).

De acordo com os dados compilados dos setores censitários, viviam no ano de 2010 quase 16 mil pessoas no entorno das dunas de Cabo Frio, Arraial do Cabo e Armação dos Búzios. Apesar das dunas serem consideradas pela legislação federal áreas de preservação permanente, e de parte delas estar inserida em Unidades de Conservação, sua preservação encontra-se ameaçada não apenas pela expansão urbana, mas também pela previsão de novos empreendimentos turísticos na região.

O cenário atual já é preocupante, uma vez que o campo de dunas de Tucuns foi ocupado por um empreendimento hoteleiro; nas dunas do Peró parte da urbanização encontra-se no limite das dunas móveis e as obras de um empreendimento imobiliário encontram-se embargadas por ação do Ministério Público, mas ainda sem uma decisão final; a duna Dama Branca, da praia do Forte em Cabo Frio, vem diminuindo de tamanho progressivamente devido às construções no seu entorno que barram a passagem da areia; em Arraial do Cabo encontra-se ainda um campo de dunas relativamente bem preservado que já começa a ser ocupado irregularmente. 

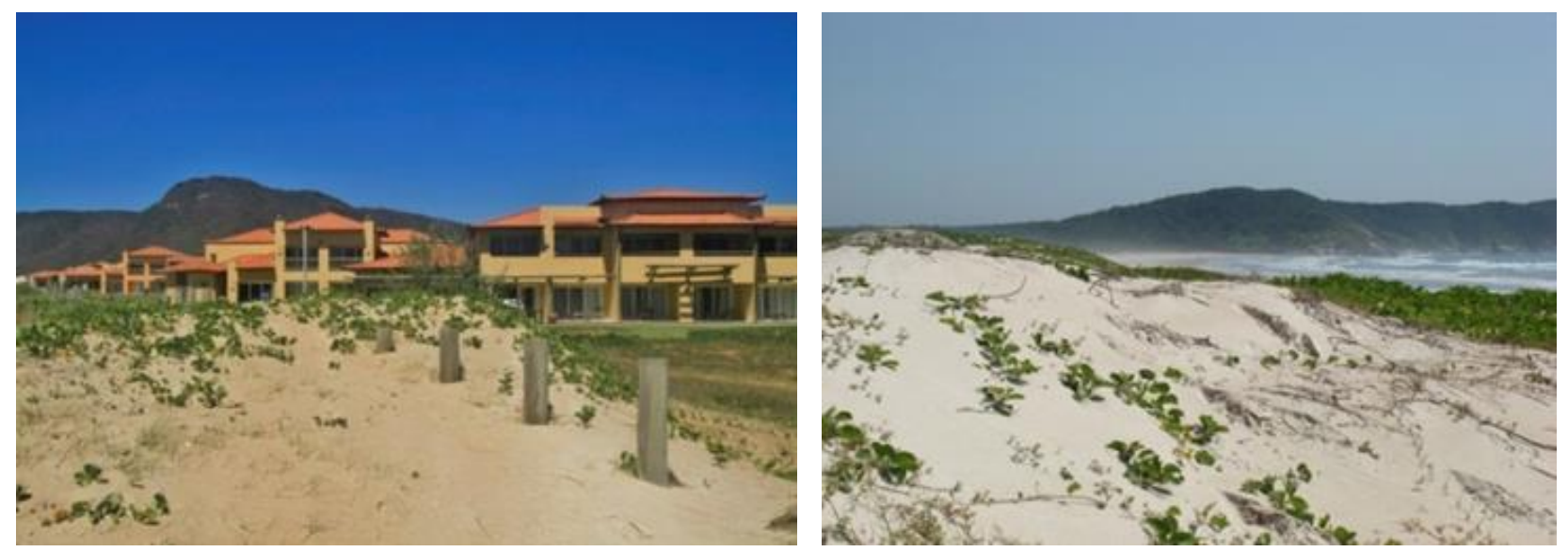

Figura 8. Em sentido horário: empreendimento hoteleiro construído sobre o campo de dunas de Tucuns (Foto: Kátia Mansur); Dunas na praia do Peró onde um empreendimento turístico pretende se instalar (Foto: Flavia Lins de Barros); Ocupações irregulares em campo de dunas na praia da Massambaba em Arraial do Cabo. (Foto: Flavia Lins de Barros).

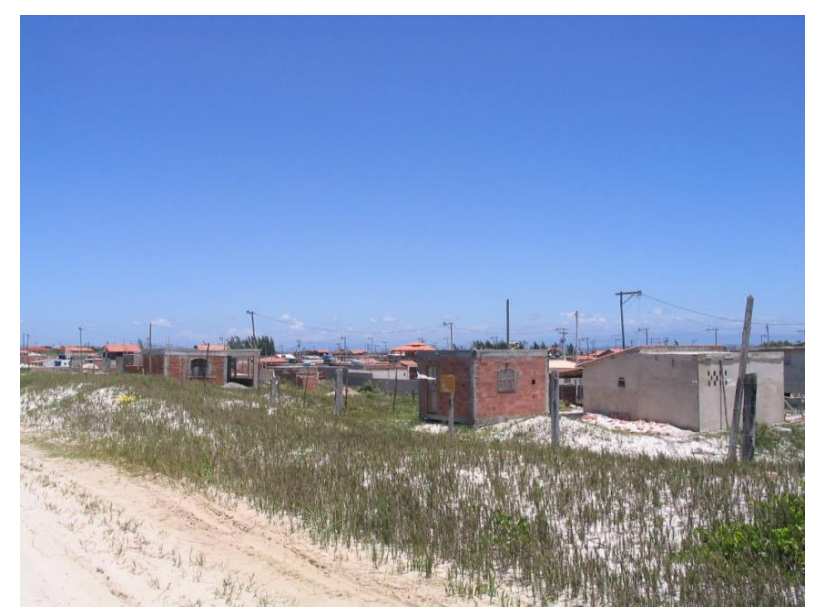

Destaca-se a pressão sobre os costões rochosos, considerados pelo Código Florestal como áreas de preservação permanente, especialmente no município de Armação dos Búzios (Figura 9). Os costões, zonas de transição entre o ambiente continental e o marinho, possuem papel de suporte para o desenvolvimento da vida marinha. Não menos preocupante é o licenciamento para construção de uma estrutura portuária na área de ocorrência dos beachrocks de Jaconé, cujo licenciamento ambietal das obras também está embargado por ação do Ministério Público. Estas rochas foram descritas por Charles Darwin, em 1832 e recentemente o INEPAC e o Conselho de Cultura do estado aprovaram seu tombamento, mas o processo de efetivação não prosseguiu.

Um outro caso exemplar foi o licenciamento, atualmente cancelado, de um empreendimento iniciado na área de influência do denominado Mangue de Pedra, em Armação de Búzios, um manguezal que se desenvolve sobre rochas e cujo aporte de água doce é dado pela descarga de água subterrânea na praia. A mata no entorno do manguezal é frequentemente objeto de invasões, desmatamentos e queimadas, apesar de ser considerada área de preservação permanente pela legislação brasileira. Existe uma campanha há muitos anos para a criação de uma Unidade de Conservação na área (OBRACZKA et al., 2018). 


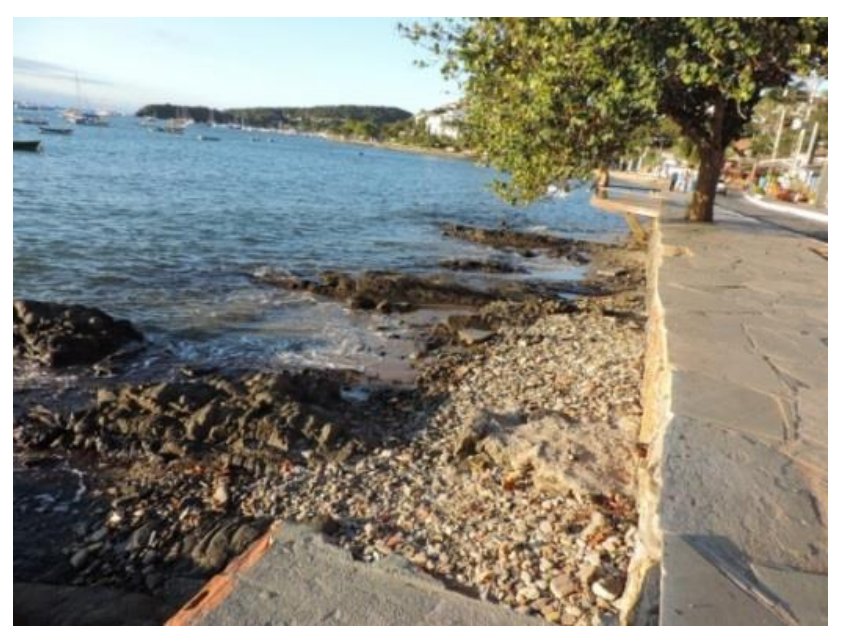

Figura 9. Em sentido horário: Orla no centro de Búzios construída sobre costão rochoso (Foto: Daniel Souza); foto do centro: Beachrocks de Jaconé (Foto Kátia Mansur); e foto da direira: Mangue de Pedra em Armação dos Búzios. (Foto: Flavia Lins de Barros).
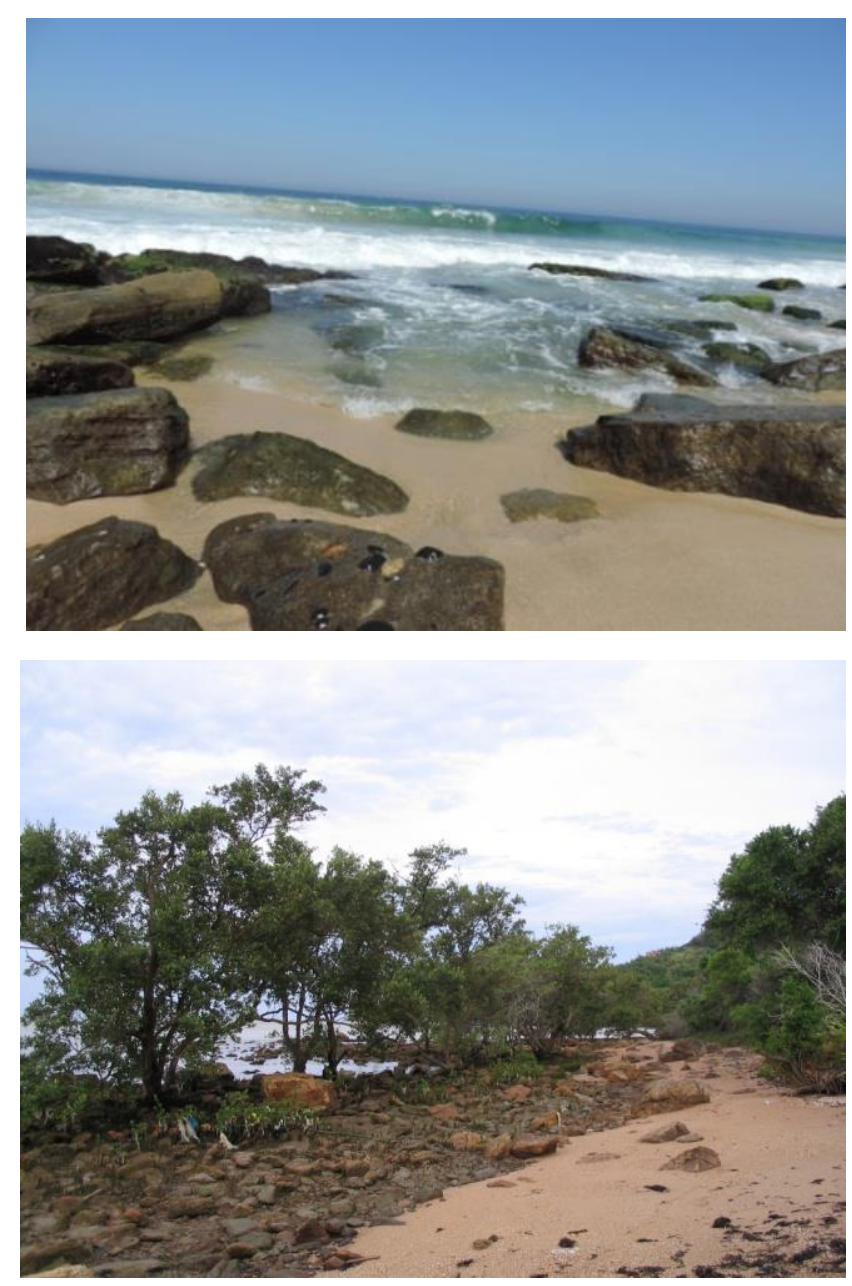

Vale acrescentar a existência de Unidades de Conservação (UCs) de proteção integral e de uso sustentável em muitas outras áreas da região, como o Parque Estadual da Costa do Sol, uma UC formada por um mosaico de áreas desconectadas, a APA de Maricá, a APA de Massambaba e a APA do Pau-Brasil, todas estaduais e a Reserva Extrativista Marinha de Arraial do Cabo, esta última de instância federal.

Uma análise que considerou os serviços ecossistêmicos prestados pela Geodiversidade nestes sítios ameaçados é mostrada na Tabela 4. Pode-se observar que os Beachrocks de Jaconé e o Mangue de Pedra atendem aos cinco tipos de serviços. Vale, ainda, ressaltar que todos os locais fazem parte da proposta do Geoparque Costões e Lagunas do RJ (MANSUR et al., 2012). 
Tabela 4. Serviços Ecossistêmicos da Geodiversidade ameaçada na Região dos Lagos

\begin{tabular}{|c|c|c|}
\hline Geossítios & $\begin{array}{l}\text { Serviços Ecossistêmicos da } \\
\text { Geodiversidade }\end{array}$ & Descrição \\
\hline \multirow{4}{*}{ Restinga de Maricá } & Regulação & Dunas (controle de inundações e erosão) \\
\hline & Cultural & Populações tradicionais (pescadores) \\
\hline & Provisão & Pesca \\
\hline & Conhecimento $\left(^{*}\right)$ & Excursões didáticas \\
\hline \multirow{5}{*}{ Beachrocks de Jaconé } & Regulação & Controle de Erosão \\
\hline & Suporte & Habitat: Mariscos \\
\hline & Provisão & Mariscos e peixes \\
\hline & Cultural & Uso das rochas pelos habitantes pré-históricos \\
\hline & Conhecimento $\left(^{*}\right)$ & $\begin{array}{l}\text { História da ciência (Darwin) e excursões didáticas e } \\
\text { geoparque }\end{array}$ \\
\hline \multirow{4}{*}{$\begin{array}{l}\text { Sistema Lagunar de } \\
\text { Araruama }\end{array}$} & Suporte & Cianobactérias - construtoras dos estromatólitos \\
\hline & Provisão & Sal \\
\hline & Cultural & Salinas e sambaquis \\
\hline & Conhecimento $\left({ }^{*}\right)$ & Excursões didáticas \\
\hline \multirow{4}{*}{ Dama Branca (dunas) } & Regulação & Dunas (controle de inundações e erosão) \\
\hline & Suporte & Habitat (espécies endêmicas) \\
\hline & Cultural & Bem cultural tombado pelo Estado \\
\hline & Conhecimento $\left(^{*}\right)$ & Excursões didáticas \\
\hline \multirow{4}{*}{ Dunas do Peró } & Regulação & Dunas (controle de inundações e erosão) \\
\hline & Suporte & Habitat (espécies endêmicas) \\
\hline & Cultural & Sambaquis \\
\hline & Conhecimento $\left(^{*}\right)$ & Excursões didáticas \\
\hline \multirow{4}{*}{$\begin{array}{l}\text { Costões rochosos de } \\
\text { Búzios }\end{array}$} & Regulação & Controle da erosão \\
\hline & Suporte & $\begin{array}{l}\text { Vida nos costões e recifes de corais e espécies vegetais } \\
\text { endêmicas }\end{array}$ \\
\hline & Provisão & Mariscos e peixes \\
\hline & Conhecimento $\left(^{*}\right)$ & Excursões didáticas \\
\hline \multirow{5}{*}{ Mangue de Pedra } & Regulação & Controle de erosão (falésias) \\
\hline & Suporte & Aquífero e rochas que suportam o ecossistema \\
\hline & Provisão & Mariscos \\
\hline & Cultural & Quilombolas \\
\hline & Conhecimento $\left(^{*}\right)$ & Excursões didáticas \\
\hline
\end{tabular}

(*) Todos são geossítios (= patrimônio geológico in situ, segundo Brilha [2016]) da proposta de Geoparque Costões e Lagunas (MANSUR et al., 2012). 
O mapa síntese (Figura 10) buscou retratar os principais desafios para a gestão costeira da Região dos Lagos, localizando as praias mais vulneráveis à erosão costeira - com ou sem impactos, as lagunas e o lençol freático sujeitos à poluição, os geossítios ameaçados pela pressão urbana ou pelo planejamento de grandes projetos e a pressão urbana e turística. Destaca-se, neste sentido, a infraestrutura portuária de Jaconé, que ameaça os já mencionados beachrocks, (rochas de praia), e os resorts turísticos nas dunas de Maricá e Cabo Frio. Outro aspecto mostrado no mapeamento é a distribuição da densidade populacional, que revela a maior ocupação das orlas das praias ou das lagunas, em detrimento das áreas mais continentais, confirmando a tendência global de maior ocupação das áreas costeiras.

Apesar disso, encontram-se ainda pouco ocupados longos trechos da praia da Massambaba em Arraial do Cabo, inserida em uma unidade de conservação, e boa parte da praia de Unamar em Cabo Frio, localizada próxima à uma área militar da Marinha do Brasil, embora esta última tenha apresentando forte crescimento nos últimos anos. Estas duas áreas merecem atenção especial, pois a praia da Massambaba apresenta elevada vulnerabilidade à erosão costeira e, se for urbanizada sem planejamento adequado, poderá se tornar uma área com fortes impactos por ressacas. Enquanto isso, Unamar se caracteriza por relevo muito plano, e constantemente sofre com alagamentos, afloramento do lençol freático, e com o retorno das águas da rede de esgoto representando risco para a saúde.

Este mapeamento dos diferentes elementos da vulnerabilidade costeira associado à identificação da geodiversidade revela em escala regional a distribuição espacial das principais problemáticas identificadas no presente trabalho e auxilia a compreensão das prioridades para gestão.

\section{Desafios para gestão costeira integrada da Região dos Lagos}

A partir da análise apresentada no presente trabalho, é possível traçar algumas recomendações e reflexões para a gestão costeira integrada da Região dos Lagos. A partir dos dados apresentados e do mapeamento síntese proposto, foram destacados os seguintes problemas críticos na região:

- Vulnerabilidade física das praias à erosão costeira e ressacas;

- Poluição por esgoto doméstico das lagunas e lençol freático;

- Conflitos entre empreendimentos portuários e turísticos e conservação da geo e biodiversidade;

- Pressão urbana e turística sobre dunas e costões; 


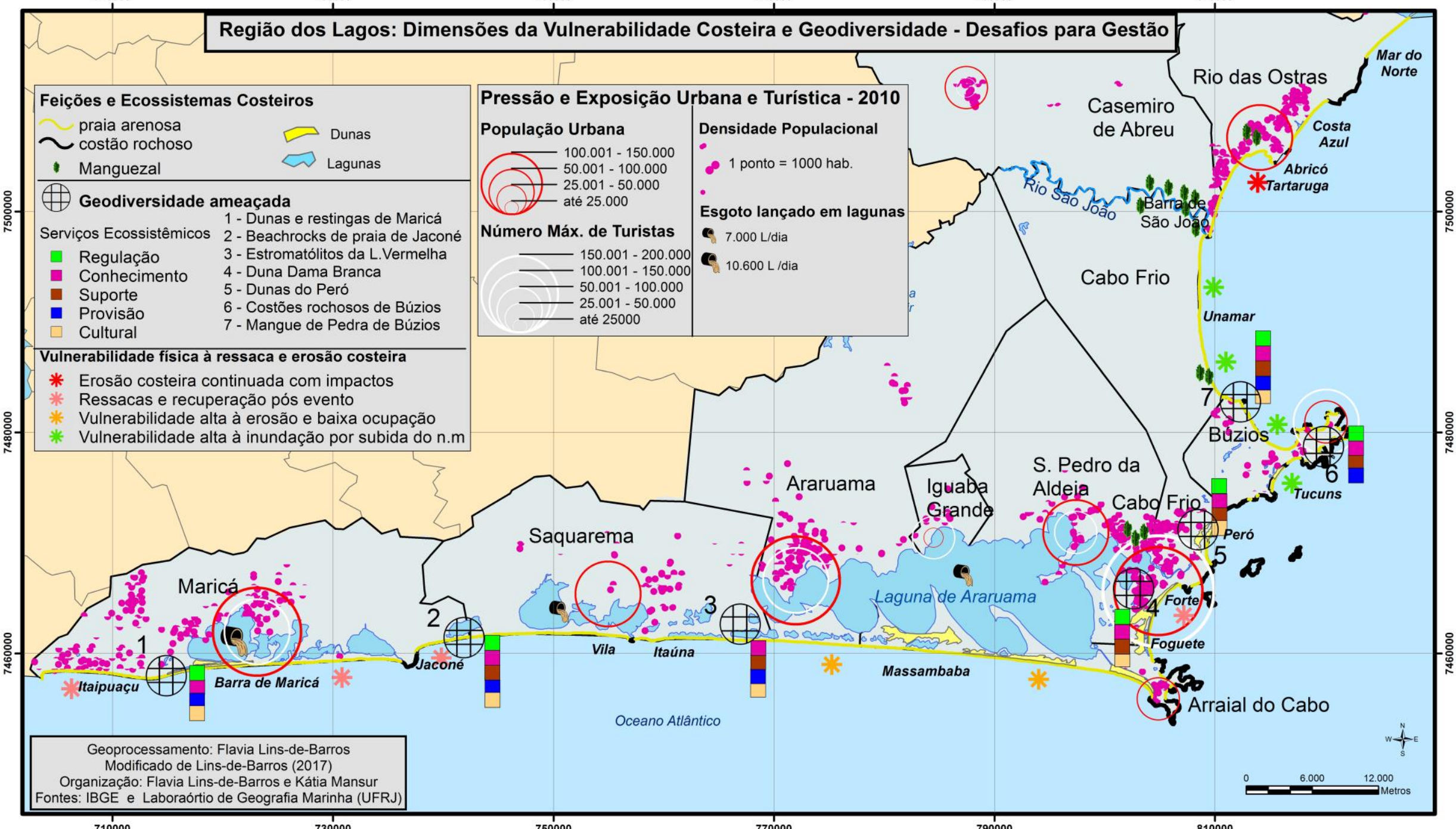

710000 730000

Figura 10. Mapa da vulnerabilidade costeira e dos serviços ecossistêmicos prestados pela geodiversidade da Região dos Lagos, alertando para os principais problemas e ameaças para a gestão costeira da região. Fonte: Modificado de Lins-de-Barros (2017). 
Tais problemáticas apresentam-se de modo geral em toda a região, mas, conforme demonstrado pela matriz e diagrama de análise vulnerabilidade costeira integrada - DACVI (DICVA, em inglês) proposto por Lins-de-Barros (2017), aplicados à Região dos Lagos, ocorre concentração de problemas das dimensões social, ecológica e física da vulnerabilidade nos municípios de Maricá e Saquarema, seguidos por Araruama e Armação dos Búzios. Estes mesmos municípios também concentram importantes geossítios que merecem atenção especial pelos serviços prestados. Instrumentos estaduais de gestão costeira, tais como o zoneamento ecológico econômico costeiro, iniciado na região sul do estado recentemente, devem incluir estas temáticas como primordiais para a Região dos Lagos.

Em escala intramunicipal, é urgente que os Projetos Orla, já existentes em todos os municípios da região (com exceção de Maricá), incorporem o problema da vulnerabilidade física das praias à erosão costeira e ressacas do mar e dialoguem com os planos diretores municipais, a fim de evitar ocupação da faixa dinâmica das praias e de áreas de preservação permanente, como os costões e dunas. Políticas direcionadas ao turismo sustentável também seriam importantes para diminuir a pressão desta atividade nos ecossistemas e geossítios, assim como estruturar melhor os serviços básicos dos municípios para esta atividade.

A existência de Unidades de Conservação também não tem sido suficiente para impedir invasões, queimadas e tentativas de licenciamento de empreendimentos turísticos e industriais em áreas consideradas valiosas ambientalmente e vulneráveis, segundo a análise realizada.

\section{Conclusão}

A abordagem proposta no presente trabalho aponta para questões intrínsecas à zona costeira, a partir dos conceitos de vulnerabilidade costeira integrada e da geodiversidade. Apesar de alguns problemas, como a poluição por esgoto doméstico ou a pressão turística, atingir de modo geral muitas cidades brasileiras, suas consequências no ambiente costeiro apresentam certas particularidades que não podem ser ignoradas na definição de ações de gestão costeira. Tais particularidades são ressaltadas por Robert de Moraes (MORAES, 1999) que aponta que as zonas costeiras possuem localização diferenciada que apresenta características naturais e de ocupação que Ihe são próprios. O autor aponta ainda que "[...] os espaços costeiros ainda bem preservados conhecem no presente uma valorização que deveria limitar as possibilidades de sua exploração a uma gama de atividades restritas [...]" (MORAES, 1999, p. 19).

A Região dos Lagos no estado do Rio de Janeiro retrata de maneira muito clara estas particularidades da zona costeira apresentando grande geodiversidade e variedade ecossistêmica, complexa dinâmica física em seu litoral e forte atração turística. Por outro lado, ainda apresenta espaços preservados, mas que se encontram ameaçados pela pressão urbana e turística, assim como pela atividade portuária. Todas estas características exigem atenção especial da gestão costeira dessa região a fim de salvaguardar a qualidade ambiental e social ali existente. O presente trabalho apresentou alguns dos principais desafios identificando as praias mais vulneráveis à erosão costeira ou às ressacas do mar, os geossítios (patrimônio geológico) mais importantes ameaçados, e a pressão urbana e turística sobre os principais ecossistemas. 
Submetido em 28 de maio de 2018. Aceito para publicação em 16 de agosto de 2018. 
Referências

ADGER, W. N.; BROOKS N.; BENTHAM, G.; AGNEW, M.; ERIKSEN, S. New indicators of vulnerability and adaptive capacity. Tyndall Centre for Climate Change Research (Technical Report 7: Final Project Report), 2004. 122p. Disponível em: $<$ http://www.tyndall.ac.uk/publications/tech_reports/tech_reports.shtml>. Aceso em: 1 ago. 2018.

AVELAR, S.; TOKARCZVK, P. Analysis of Land Use and Land Cover Change in a Coastal Area of Rio de Janeiro Using Remotely Sensed Data. Journal of Applied Remote Sensing, v. 8, n. 1, 2014. DOI: 10.1117/1.JRS.8.083631.

AZEVEDO. Modelagem da capacidade de suporte da laguna de Saquarema - RJ - após abertura de uma conexão permanente com o mar. 117 p. Dissertação (Mestrado) - PósGraduação em Ciência Ambiental, Universidade Federal Fluminense, 2005.

ABRANTES, E. A.; MENDONÇA, M. C. Uma nova espécie de Arlea Womersley do sudeste do Brasil (Collembola, Isotomidae). Revista Brasileira de Zoologia, Curitiba, v. 22, n. 4, 2005.

BARBOSA, K. C. Turismo em Armação dos Búzios (RJ, Brasil): percepções locais sobre os problemas da cidade e diretrizes prioritárias de apoio à gestão ambiental. 124 p. Dissertação (Mestrado) - Universidade Federal Fluminense, Niterói, 2003.

BIDEGAIN, P. Lagoa de Araruama - Perfil Ambiental do Maior Ecossistema Lagunar Hipersalino do Mundo / Paulo Bidegain, Carlos Bizerril. Rio de Janeiro: Semads, 2002. 160 p. ISBN 8587206-15-X.

BRILHA, J. Inventory and Quantitative Assessment of Geosites and Geodiversity Sites: a Review. Geoheritage, 2016. DOI 10.1007/s12371-014-0139-3

BULHOES, E.; FERNANDEZ, G.; OLIVEIRA FILHO, S. R., PEREIRA, T. G. Coastal Impacts Induced by Storm Waves between Cape Frio and Cape Buzios, Rio de Janeiro, Brazil. In: VILACONCEJO, A.; BRUCE, E.; KENNEDY, D. M.; MCCARROLL, R. J. (eds.). Proceedings of the 14th International Coastal Symposium (Sydney, Australia). Journal of Coastal Research, Coconut Creek (Florida), Special Issue, n. 75, p. 1047-1051, 2016. ISSN 0749-0208.

CASTRO, J. W. A.; SUGUIO, K.; CUNHA, A. M.; GUEDES, E.; TÂMEGA, F. T. S.; RODRIGUEZ, R. R. Rochas de Praia (Beachrocks) da Ilha do Cabo Frio, Arraial do Cabo: Registro Geológico Ímpar da Transição Pleistoceno - Holoceno no Estado do Rio de Janeiro. Anuário do Instituto de Geociências da UFRJ, v. 35, n. 1, p. 236-241, 2012.

CABRAL, C. L.; CASTRO, J. W. A.; CUNHA, A. M. Registros das Variações do Nível Relativo do Mar na Península de Armação dos Búzios, Rio de Janeiro: Análise de Dados Faciológicos e Geocronológicos. Anuário do Instituto de Geociências da UFRJ, v. 41, n. 1, p. 130-141, 2018.

CASTRO, J. W. A.; FERNANDES, D.; DIAS, F. F. Monitoramento do Processo de Erosão Costeira na Praia das Tartarugas, Rio das Ostras - Estado do Rio de Janeiro / Brasil: Aplicação de Metodologia Quantitativa. Revista da Gestão Costeira Integrada, v. 11, n. 3, p. 355-368, 
2011. Disponível em: <http://www.aprh.pt/rgci/pdf/rgci-276_Castro.pdf DOI:10.5894/rgci276>. Acesso em: 1 ago. 2018.

DIAS, F. F.; SEOANE, J. C. S., CASTRO, J. W. A. Evolução da Linha de Praia do Peró, Cabo Frio / RJ nos Últimos 7.000 Anos. Anuário do Instituto de Geociências da UFRJ, v. 32, n. 1, p. 9-20, 2009.

ENGLISH NATURE. Revealing the value of nature. Birmingham: W Lake, 2002. 38p.

FERNANDEZ, G. B., BULHOES, E.; ROCHA, T. B.. Impacts of Severe Storm Ocurred in April 2010 along Rio de Janeiro Coast, Brazil. Journal of Coastal Research, Special Issue (Proceedings of the 11th International Coastal Symposium, Szczecin, Poland), v. 64, 2011. ISSN 0749-0208.

GRAY, M. Geodiversity: valuing and conserving abiotic nature. Chichester: Wiley-Blackwell. 2004. 434p.

Geodiversity: valuing and conserving abiotic nature. 2. ed. Chichester: John Wiley \& Sons, 2013. 495p.

IBGE. Censo demográfico 2010. 2010. Disponível em: <www.ibge.gov.br>.. Acesso em: 31 jan. 2016.

IPCC. Summary for Policymakers. 2007. Disponível em: <http://www.ipcc.ch/>. Acesso em: 1 set. 2007.

IGNARRA, S. M. N. Os arenitos de praia de Itaipuaçu e Jaconé - RJ: origem, idade, distribuição e influência no fluxo de sedimentos. 60 p. Dissertação (Mestrado) - Programa de PósGraduação em Geologia, Universidade Federal do Rio de Janeiro, 1989.

LINS-DE-BARROS, F. M. Risco e Vulnerabilidade à Erosão Costeira no Município de Maricá. 147 p. Dissertação (Mestrado em Geografia) - Programa de Pós-Graduação em Geografia, Universidade Federal do Rio de Janeiro, Rio de Janeiro, 2005. Disponível em: <http://objdig.ufrj.br/16/teses/648563.pdf>. Acesso em: 1 ago. 2018.

. Contribuição metodológica para análise local da vulnerabilidade costeira e riscos associados: estudo de caso da Região dos Lagos, Rio de Janeiro. Tese de Doutorado - Universidade Federal do Rio de Janeiro, 297p. 2010.

. Integrated coastal vulnerability assessment: A methodology for coastal cities management integrating socioeconomic, physical and environmental dimensions - Case study of Região dos Lagos, Rio de Janeiro, Brazil. Ocean and Coastal Management, v. 149, p. 1-11, 2017.

LINS-DE-BARROS, F. M.; MUEHE, D. Avaliação local da vulnerabilidade e riscos de inundação na zona costeira da Região dos Lagos, Rio de Janeiro. Quaternary and Environmental Geosciences. v. 2, n. 1, p.55-66, 2010.

LINS-DE-BARROS, F. M.; ZEIDAN, F.; LIMA, R. F. Adaptações e percepção da população a eventos de ressaca do mar no litoral de Maricá, Rio de Janeiro, Brasil. Revista de Gestão Costeira Integrada [online], v. 16, n. 2, p. 147-161, 2016. ISSN 1646-8872. Disponível em: <http://dx.doi.org/10.5894/rgci591>. Acesso em: 1 ago. 2018. 
MANSUR, K. L. Diretrizes para Geoconservação do Patrimônio Geológico do Estado do Rio de Janeiro: o Caso do Domínio Tectônico Cabo Frio, Rio de Janeiro. 214p. Tese (Doutorado em Geologia) - Instituto de Geociências, Universidade Federal do Rio de Janeiro, 2010.

MANSUR, K. L., CARVALHO, I. S. Characterisation and valuation of the geological heritage identified in the Peró Dune Field, State of Rio de Janeiro, Brazil. Geoheritage, v. 3, p. 97-115, 2011.

MANSUR, K. L.; RAMOS, R. R. C.; GISEÉ, G. Beachrock de Jaconé: uma pedra no caminho de Darwin. In: WINGE, M. et al (ed.). Sítios geológicos e paleontológicos do Brasil. V. 3. Brasília: CPRM, 2018. p. 143-160.

MANSUR, K. L.; RAMOS, R. R. C.; GODOY, J. M. O.; NASCIMENTO, V. M. R. Beachrock de Jaconé, Maricá e Saquarema - RJ: importância para a história da ciência e para o conhecimento geológico. Revista Brasileira de Geociências, v. 4, n. 2, p. 290-303, 2011.

MCFADDEN, L. Vulnerability Analysis: A Useful Concept for Coastal Management? In: MCFADDEN, L.; NICHOLLS, R.; PENNING-ROWSELL, E. (Ed.). Managing Coastal Vulnerabilty. Elsevier, 2007. p. 15-28.

MOHRIAK, W. U.; BARROS, A. Z. Novas evidências de tectonismo cenozóico na região sudeste do Brasil: o gráben de Barra de São João na plataforma continental de Cabo Frio, Rio de Janeiro. Revista Brasileira de Geociências, v. 20, n. 1-4, p. 187- 196, 1990.

MORAES, A. C. R. Contribuições para gestão da zona costeira do Brasil: Elementos para uma Geografia do Litoral Brasileiro. São Paulo: Hucitec, 1999.

MUEHE, D. Erosão costeira: tendência ou eventos extremos? O litoral entre Rio de Janeiro e Cabo Frio, Brasil. Revista de Gestão Costeira Integrada, v. 11, n. 3, p. 315-325, 2011. DOI: $10.5894 /$ rgci282.

MUEHE, D.; BELLIGOTTI, F. M.; LINS-DE-BARROS, F. M.; OLIVEIRA, J. F.; MAIA, L. F. P. G. Potential vulnerability to climate change of the beach-dune system of the Peró coastal plain, Rio de Janeiro, Brazil. Pan-American Journal of Aquatic Science, v. 5, p. 67-276, 2010.

MUEHE, D.; VALENTINI, E. O Litoral do Estado do Rio de Janeiro: uma caracterização físicoambiental. Rio de Janeiro: Ed. FEMAR, 1998. 99 p.

MUEHE, D.; LINS-DE-BARROS, F. M. The Beaches of Rio de Janeiro. In: SHORT, A.; KLEIN, A. (org.). Beach Systems of Brazil. Ed. Springer, 2016. p. 363-396.

OBRACZKA, M.; MANSUR, K. L.; SILVA JR, G.C. Towards Sustainability and Protection of Threatened Coastal Ecosystems: Management Strategies for a Rare Stone Mangrove in Gorda Beach, Armação dos Búzios, Brazil. In: MAKOWSKI, C.; FINKL, C. W. (ed.). Threats to Mangrove Forests, Coastal Research Library, v. 25, 2018. Disponível em: <https://doi.org/10.1007/978-3-319-73016-5_17>. Acesso em: 1 ago. 2018.

PINTO, V. C. S.; SILVA, A. L. C.; FARIA, C. S. Dinâmica Sazonal do Arco Praial de JaconéSaquarema (RJ) entre os Anos de 2012 e 2016. In: CONGRESSO BRASILEIRO DE GEOGRAFIA FÍSICA APLICADA, 17. Anais... Campinas: UNICAMP, 2017. p. 2842-2853. DOI: $10.20396 /$ sbgfa.v1i2017. 
SCHMITT, R. S. A orogenia Búzios - caracterização de um evento tectono-metamórfico no Domínio Tectônico Cabo Frio - sudeste da Faixa Ribeira. 271 p. Tese (Doutorado) - PósGraduação em Geologia, Departamento de Geologia, Universidade Federal do Rio de Janeiro, Rio de Janeiro, 2001.

SILVA, J. G.; OLIVEIRA, A. S. A vegetação de restinga no Município de Maricá - RJ. Acta Bot. Bras., Feira de Santana, v. 3, n. 2, supl. 1, 1989

SILVA, M. L. N. Geodiversidade da Cidade do Natal: Valores, Classificações e Ameaças. 170 f. Monografia (Trabalho de Conclusão de Curso) - Departamento de Geologia, Universidade Federal do Rio Grande do Norte, Natal, 2016.

SILVA, M. L. N.; NASCIMENTO, M. A. L. Os Valores da Geodiversidade de Acordo com os Serviços Ecossistêmicos Sensu Murray Gray Aplicados a Estudos In Situ na Cidade do Natal (RN). Caderno de Geografia, v. 26, número especial 2, 2016. ISSN 2318-2962.

TURCQ, B.; MARTIN, L.; FLEXOR, J. M.; SUGUIO, K.; PIERRE, C.; TASAYCO ORTEGA, L. Origin and evolution of the Quaternary coastal plain between Guaratiba and Cabo Frio, State of Rio de Janeiro, Brazil. In: KNOOPERS, B.; BIDONE, E. D.; ABRAÃO, J. J. (ed.). Environmental geochemistry of coastal lagoon systems of Rio de Janeiro, Brazil. Rio de Janeiro: Universidade Federal Fluminense, Geoquímica Ambiental, 1999. p.25-46.

VASCONCELOS, C. O. Modern Dolomite Precipitation and Diagenesis in a Coastal Mixed Water System (Lagoa Vermelha, Brazil): A Microbial Model for Dolomite Formation under Anoxic Conditions. Thesis (PhD) - Eidgenossische Technische Hochschule, Zurich, 1994.

WOODROFFE, C. The natural resilience of Coastal Systems: Primary Concepts. In: MCFADDEN, L.; NICHOLLS, R.; PENNING-ROWSELL, E. (Ed.). Managing Coastal Vulnerabilty, Elsevier, p. 45-60, 2007. 